\title{
Isotopic evidence of boron in precipitation originating from coal burning in Asian continent
}

\author{
Masahiro SaKata, * Masahiro NATSUmi and YukinOri TANi \\ Institute for Environmental Sciences, University of Shizuoka, 52-1 Yada, Shizuoka 422-8526, Japan
}

(Received February 23, 2009; Accepted July 7, 2009)

\begin{abstract}
The boron concentration and isotopic composition $\left(\delta^{11} \mathrm{~B}\right)$ of precipitation collected from December 2002 to March 2006 at three sites on the Japan Sea coast were measured. Those sites have been considerably affected by the long-range transport of air pollutants from the Asian continent during winter and spring when the airflows from the Asian continent are predominant. The boron concentration in the precipitation increased primarily during winter whereas the $\delta^{11} \mathrm{~B}$ decreased during winter or spring. It is assumed that this decrease in $\delta^{11} \mathrm{~B}$ is not associated with a Rayleigh distillation process, because the previous $\delta \mathrm{D}$ values of the precipitation collected at a site on the Japan Sea coast did not decrease in the same manner. A weak correlation $\left(r^{2}=0.13-0.24, P<0.01\right)$ was observed between $\delta^{11} \mathrm{~B}$ and the nonsea-salt sulfate (nss- $\left.\mathrm{SO}_{4}{ }^{2-}\right) / \mathrm{B}$ ratio at each site, suggesting that boron in the precipitation originate primarily from two sources. The first source, which is characterized by high $\delta^{11} \mathrm{~B}$ and nss- $\mathrm{SO}_{4}{ }^{2-} / \mathrm{B}=0$, is seawater. At the northern site, the enrichment factor for boron in the precipitation relative to seawater approached unity during winter. This implies that much of the boron in the precipitation is derived from unfractionated sea salts rather than gaseous boron evaporated from seawater. The second source is characterized by low $\delta^{11} \mathrm{~B}$ and high nss- $\mathrm{SO}_{4}{ }^{2-} / \mathrm{B}$ ratio. Most of the nss- $\mathrm{SO}_{4}{ }^{2-}$ in the precipitation originates from anthropogenic combustion activities in the Asian continent based on the previous model calculations. Coal accounts for a major portion of the total primary energy supply in China. Moreover, coal enriches boron and represents generally negative $\delta^{11} \mathrm{~B}$ values. Hence, we propose that the emission of boron from coal burning is the most likely second source. Thus, boron isotopes may be useful as tracers of coal-burning plumes from the Asian continent.
\end{abstract}

Keywords: boron isotopes, coal burning, trace elements, Asian continent, long-range transport

\section{INTRODUCTION}

In recent years, there have been increased environmental concerns associated with the long-range transport of air pollutants from the Asian continent to Japan and even to North America. In Japan, it has been reported that various substances, including non-sea-salt sulfate (nss$\mathrm{SO}_{4}{ }^{2-}$ ), heavy metals and organic compounds, are transported from the Asian continent to Japan during winter and spring when the airflows from the Asian continent are dominant (Mukai et al., 1990, 1994; Ichikawa et al., 1998; Tanaka and Sakata, 2002; Sakata and Marumoto, 2005; Sakata et al., 2006). Moreover, Tanimoto et al. (2005) showed that the spring maximum of surface $\mathrm{O}_{3}$ over Japan is significantly caused by $\mathrm{NO}_{\mathrm{x}}$ from sources in China and Korea. On the other hand, Jaffe et al. (2005) and Weiss-Penzias et al. (2006) observed the export of $\mathrm{CO}, \mathrm{O}_{3}, \mathrm{Hg}^{0}$ and particles from Asian long-range transport (ALRT) during spring at the Mt. Bachelor Observatory in central Oregon, USA, suggesting that the ratio of

*Corresponding author (e-mail: sakatam@u-shizuoka-ken.ac.jp)

Copyright @ 2010 by The Geochemical Society of Japan.
$\mathrm{Hg}^{0} / \mathrm{CO}$ can be used as an effective indicator of ALRT.

On the basis of the energy balances for China in 2005 (International Energy Agency, 2008), coal accounts for $63 \%$ of the total primary energy supply, and the amount of coal consumed has increased rapidly in recent years. Various toxic trace elements, such as mercury, arsenic and lead, are contained in coal, although their concentrations are highly dependent on the types of coal and their collection sites. In China, coal combustion facilities are not sufficiently equipped with a flue gas control system that effectively removes toxic trace elements. Hence, it is considered that coal burning contributes considerably to the emissions of those elements to the atmosphere. Evaluating the contribution of toxic trace elements derived from the coal burning in the Asian continent and their wet and dry depositions in Japan is highly important for assessing their environmental risks. Tracers of emissions from coal burning are useful for such evaluation. Several tracers have been used for precipitation and aerosol samples, namely, sulfur isotopes in nss- $\mathrm{SO}_{4}{ }^{2-}$ (Kitamura et al., 1993), lead isotopes (Mukai et al., 1994), carbon isotopes in some polycyclic aromatic hydrocarbons (Tanaka and Sakata, 2002), selenium composition (Se(IV) and Se(VI)) (Kagawa et al., 2003), and concentration ratio of $\mathrm{Pb} / \mathrm{Zn}$ 
(Mukai et al., 1990). In this study, we aimed to determine the potential of boron isotopes as tracers of coalburning plumes from the Asian continent.

Boron is a major component of coal, because it is an essential nutrient in many plants. Boron has two stable isotopes, ${ }^{10} \mathrm{~B}$ and ${ }^{11} \mathrm{~B}$, the relative abundance of which is approximately 1:4. Boron isotopes are fractionated easily in nature owing to the relatively large difference in their isotopic masses, reaching up to $10 \%$ of isotope abundance variations (Williams and Hervig, 2004). Coal is dominated by ${ }^{10} \mathrm{~B}$, representing a significantly lighter boron isotopic composition ( $\delta^{11} \mathrm{~B}=-1--70 \%$ ) than most terrestrial materials (e.g., rocks, evaporates, crude oil, and water) ranging approximately from -30 to $+45 \%$ o (Williams and Hervig, 2004). The simplest explanation for this is that boron is bound in coal primarily in tetrahedral coordination, which shows a preference for ${ }^{10} \mathrm{~B}$. Boron is volatilized easily during the coal-burning processes (Meij and Te Winkel, 2007). This suggests that gaseous boron originating from coal burning reflects the isotopic composition of the coal, which is dependent on the extent of fractionation during condensation on solid or water surfaces at lower temperatures in flue gases and the atmosphere.

On the other hand, it is known that sea salt degassing from oceans and volcanic emissions are the major sources of boron in the atmosphere (Fogg and Duce, 1985; Anderson et al., 1994). The boron concentration and isotopic composition of seawater are nearly constant in all the oceans, being approximately $4.5 \mu \mathrm{g} \mathrm{L}^{-1}$ and $+39.5 \%$, respectively, although boron isotopes are fractionated largely during seawater evaporation. Rose-Koga et al. (2006) reported the deduced seawater-vapor fractionation of $+25.5 \%$. For volcanic emissions, a few data on fumarolic condensates of hydrothermal and volcanic systems have been reported (overall $\delta^{11} \mathrm{~B}$ ranges from -9.3 to $+21.4 \%$ ) (Kanzaki et al., 1979; Nomura et al., 1982; Palmer and Sturchio, 1990). If there is a marked difference in boron isotopic composition between coal burning and other sources, it will be expected that boron isotopes are useful as tracers of coal burning.

Sakata et al. collected precipitation samples every half-month from December 2002 to March 2006 at ten sites in Japan using a wet-only precipitation sampler. Some data of the wet deposition fluxes of trace elements were reported previously (Sakata and Marumoto, 2005; Sakata et al., 2006; Sakata and Asakura, 2007). In this study, we measured boron isotopes in the precipitation samples collected at three sites on the Japan Sea coast, which has been considerably affected by emissions from the Asian continent compared with the Pacific Ocean side. On the basis of these data, we investigated evidence of boron originating from the coal burning in the Asian continent, and finally, we determined the feasibility of boron

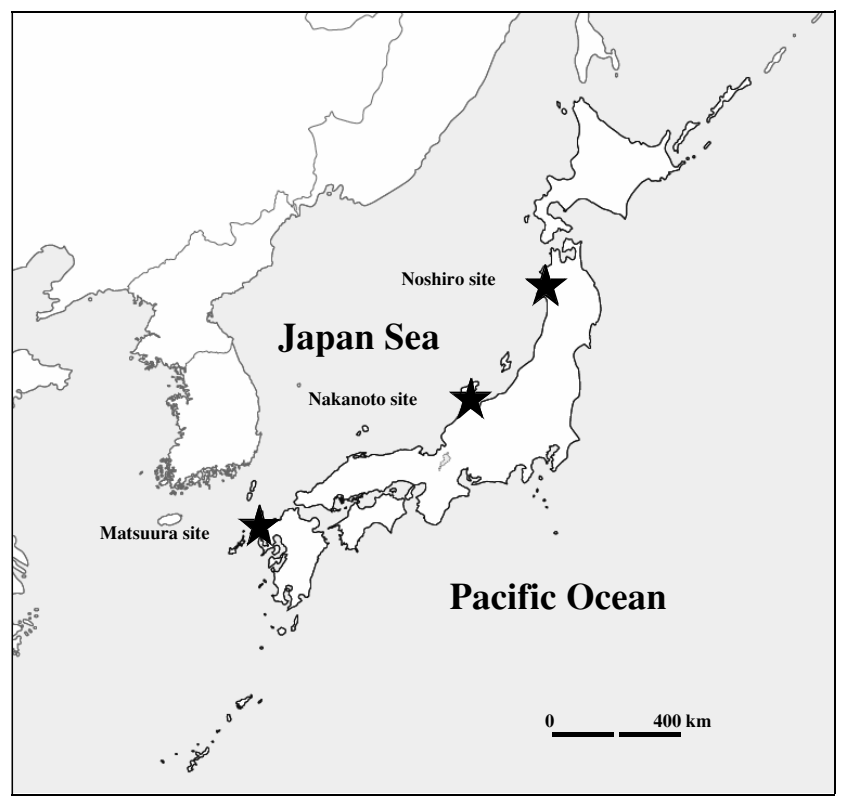

Fig. 1. Locations of sampling sites.

isotopes as effective tracers of coal burning. Because a marked difference in boron isotopic composition was found among the precipitation samples in preliminary experiments, all the isotope analyses were conducted by inductively coupled plasma quadropole mass spectrometry (ICP-QMS), which is currently widely used as a tool for trace element analysis.

\section{SAMPLES AND METHODS}

\section{Samples}

The sampling sites (i.e., Noshiro, Nakanoto and Matsuura sites) are on the Japan Sea coast, as shown in Fig. 1. These sites are in remote areas. The amounts of annual average precipitation for 2003-2005 were 1730 $\mathrm{mm}$ at the Noshiro site, $2240 \mathrm{~mm}$ at the Nakanoto site and $1940 \mathrm{~mm}$ at the Matsuura site. Large coal-fired power stations with capacities of 1,200-2,700 MW are located within roughly 5 to $20 \mathrm{~km}$ from the sites. It is likely, however, that the effects of emissions from those power stations on the sites are very small, owing to a tall stack ( $200 \mathrm{~m}$ height $)$ and a flue gas control system with electrostatic precipitator and wet scrubber (Ito et al., 2006). The sampling was conducted within the substations of electric power companies.

Precipitation samples were collected using an automatic wet-only sampler, which is equipped with two sampling trains that consist of a polycarbonate funnel (177 $\mathrm{cm}^{2}$ collection area), a Teflon tubing (10 $\mathrm{mm}$ inner diameter) and a 5-L Teflon sample bottle. The sampler is automatically covered with a lid during dry periods on the 
basis of a moisture sensor. Prior to each sampling, the funnels, bottles and tubing were carefully cleaned with $10^{-3} \mathrm{~mol} \mathrm{~L}^{-1} \mathrm{HCl}$ and Milli-Q water. All the cleaning and sample handling were conducted using gloves.

In principle, the samples were collected simultaneously at the three sites every half-month from December 2002 to March 2006. All the samples collected at each site were sent to the laboratory of the Central Research Institute of Electric Power Industry in Komae City, Tokyo. The samples were weighed immediately. For the samples used for the measurements of trace elements including boron, $\mathrm{HNO}_{3}\left(\sim 0.3 \mathrm{~mol} \mathrm{~L}{ }^{-1}\right)$ was added to dissolve the trace elements associated with atmospheric particles and to prevent their adsorption on the walls of the bottles. All the samples were stored in a refrigerator until analysis.

\section{Chemical analyses}

The precipitation samples were filtered through 0.4 $\mu \mathrm{m}$ filters. The concentrations of $\mathrm{Na}^{+}, \mathrm{NO}_{3}{ }^{-}$and $\mathrm{SO}_{4}{ }^{2-}$ in the filtrates were measured principally by ion chromatograph (Dionex, DX-AQ). In this study, $\mathrm{Na}^{+}$in rainwater is assumed to have a unique marine origin and derived from the dissolution of sea salts. The nss- $\mathrm{SO}_{4}{ }^{2-}$ concentration in the precipitation was calculated using the following equation: $\mathrm{nss}-\mathrm{SO}_{4}{ }^{2-}=\mathrm{SO}_{4}{ }^{2-}-\left(\mathrm{SO}_{4}{ }^{2-} / \mathrm{Na}^{+}\right)$seawater $\times \mathrm{Na}^{+}$where $\left(\mathrm{SO}_{4}{ }^{2-} / \mathrm{Na}^{+}\right)_{\text {seawater }}$ represents the concentration ratio of $\mathrm{SO}_{4}{ }^{2-}$ to $\mathrm{Na}^{+}$in seawater. The boron concentration was measured directly by ICP-QMS (Micromass, platform ICP). The method detection limit (MDL), which is defined as three times the standard deviation of replicate measurements of a blank solution, was approximately $0.3 \mu \mathrm{g} \mathrm{L}^{-1}$. The number of samples with a boron concentration of less than the MDL was $<3 \%$ of all the samples collected. The precision and accuracy for boron analysis were verified using a standard reference material (River Water, JAC0032) from the Japan Society for Analytical Chemistry.

Boron isotopes were determined by ICP-QMS (Hewlett Packard, HP4500). ICP-QMS has a lower degree of precision than conventional thermal ionization mass spectrometry (TIMS) and multiple collector ICPMS, but requires little sample preparation compared with TIMS. Unlike TIMS where there is no significant memory from one sample to the next, ICP-QMS can be plagued by memory effects from the spray chamber and the cones. We confirmed that these memory problems are addressed by purging the system using $0.1 \mathrm{~mol} \mathrm{~L}^{-1}$ ammonia for 60 to 150 seconds when the boron concentrations are 10 to $40 \mu \mathrm{g} \mathrm{L}^{-1}$. Boron in the precipitation samples was purified and concentrated by ion exchange using the boronspecific resin Amberlite IRA 743 (Kiss, 1988; Leeman et al., 1991; Nakamura et al., 1992). The resin was ground to a grain size of between 75 to $212 \mu \mathrm{m}$. The resin was then rinsed sequentially using $\mathrm{H}_{2} \mathrm{O}$ (Milli-Q water), 2 mol $\mathrm{L}^{-1} \mathrm{HNO}_{3}, \mathrm{H}_{2} \mathrm{O}, 3$ mol L ${ }^{-1}$ ammonia and $\mathrm{H}_{2} \mathrm{O}$. For the precipitation samples, a typical volume of several $\mathrm{mL}$ to several $100 \mathrm{~mL}$ was loaded onto the resin bed (volume, $\sim 0.5 \mathrm{~mL}$; length, $\sim 20 \mathrm{~mm}$; diameter, $\sim 6 \mathrm{~mm}$ ) to obtain 5 to $50 \mu \mathrm{g} \mathrm{L}^{-1}$ of boron concentration that enables isotope analysis with a good precision of approximately $4 \%$ (described later). Before loading the sample, its $\mathrm{pH}$ was adjusted to higher than 10 by adding $25 \%$ ammonia. Boron was eluted by loading $5 \mathrm{~mL}$ of $2 \mathrm{~mol} \mathrm{~L}^{-1} \mathrm{HNO}_{3}$. The boron recovery during this purification was more than $90 \%$ based on the concentrations measured before and after the purification in actual precipitation samples, and the procedural blank was less than $5 \%$ of the boron concentrations in the precipitation samples.

Partial loss of boron during the ion exchange separation can result in fractionation of the boron isotopes. Kakihana et al. (1977) reported the single-stage separation factors for boron isotopes between an ion exchange resin and an external solution. The separation factor was influenced by the boric acid concentration in the external solution from $1.008\left(0.5 \mathrm{~mol} \mathrm{~L}^{-1}\right)$ to $1.016(0.01 \mathrm{~mol}$ $\mathrm{L}^{-1}$ ), but not as much influenced by the kind of the resin used and operation temperature. We calculated the difference in $\delta^{11} \mathrm{~B}$ between the feed solution (i.e., precipitation sample) and the effluent solution, when the boron recovery is $90 \%$ (assumed as a minimum recovery) and the separation factor is 1.02 . The result yielded $2.5 \%$, which is less than the mean external reproducibility $(4 \%$ o as described below) for $\delta^{11} \mathrm{~B}$ measurement in this study. Thus, considerably higher recovery of boron $(\sim 100 \%)$ during the purification is not needed in this study due to a relatively low degree of precision in ICP-QMS.

The boron isotope ratio of the sample was normalized to the mean value of the NIST SRM 951 obtained just before and after the sample isotopic ratio measurement. The isotope ratio was expressed in $\delta$ unit with respect to the SRM $951\left({ }^{11} \mathrm{~B} /{ }^{10} \mathrm{~B}=4.044 \pm 0.003\right)$, and the mean external reproducibility $(1 \sigma)$ of $\delta^{11} \mathrm{~B}$ was $4 \%$.

\section{RESUlts AND Discussion}

\section{Boron concentration in precipitation}

The analytical results obtained in this study are presented in Table 1. The temporal changes in boron concentration in the precipitation from December 2002 to March 2006 at the Noshiro, Nakanoto and Matsuura sites are shown in Fig. 2. The seasonal averages, which were weighted on the basis of the amount of precipitation for each sampling period (half month), are also provided in the figure. In Japan, generally, each season includes the following three months: spring (March, April and May), summer (June, July and August), fall (September, October and November), and winter (December, January and 
Table 1. $\delta^{I l} \mathrm{~B}$ and concentrations of $\mathrm{B}, \mathrm{Na}^{+}$, nss- $\mathrm{SO}_{4}{ }^{2-}$ and $\mathrm{NO}_{3}{ }^{-}$in precipitation for each half-month from December 2002 to March 2006 at Noshiro, Nakanoto and Matsuura sites

(a) Noshiro site

\begin{tabular}{|c|c|c|c|c|c|c|c|c|c|c|c|}
\hline Time & $\begin{array}{l}\delta^{11} \mathrm{~B} \\
(\% 0)\end{array}$ & $\begin{array}{c}\mathrm{B} \\
\left(\mu \mathrm{g} \mathrm{L}^{-1}\right)\end{array}$ & $\begin{array}{c}\mathrm{Na}^{+} \\
\left(\mathrm{mg} \mathrm{L}^{-1}\right)\end{array}$ & $\begin{array}{c}\mathrm{nss} \mathrm{SO}_{4}{ }^{2-} \\
\left(\mathrm{mg} \mathrm{L}^{-1}\right)\end{array}$ & $\begin{array}{c}\mathrm{NO}_{3}^{-} \\
\left(\mathrm{mg} \mathrm{L}^{-1}\right)\end{array}$ & Time & $\begin{array}{l}\delta^{11} \mathrm{~B} \\
(\% 0)\end{array}$ & $\begin{array}{c}\mathrm{B} \\
\left(\mu \mathrm{g} \mathrm{L}^{-1}\right)\end{array}$ & $\begin{array}{c}\mathrm{Na}^{+} \\
\left(\mathrm{mg} \mathrm{L}^{-1}\right)\end{array}$ & $\begin{array}{c}\mathrm{nns} \mathrm{SO}_{4}{ }^{2-} \\
\left(\mathrm{mg} \mathrm{L}^{-1}\right)\end{array}$ & $\begin{array}{c}\mathrm{NO}_{3}^{-} \\
\left(\mathrm{mg} \mathrm{L}^{-1}\right)\end{array}$ \\
\hline \multirow[t]{2}{*}{ Dec-02 } & 28.5 & 2.7 & 2.7 & 2.6 & 1.1 & Aug-04 & 35.9 & 7.7 & 11.3 & 0.8 & 0.5 \\
\hline & 29.2 & 5.5 & 9.9 & 1.5 & 1.1 & & ND & 1.6 & 1.2 & 0.2 & 0.2 \\
\hline \multirow[t]{2}{*}{ Jan-03 } & 26.0 & 7.2 & 16.7 & 2.3 & 1.4 & Sep-04 & 33.8 & 5.1 & 7.8 & 0.5 & 0.4 \\
\hline & 28.6 & 6.0 & 16.0 & 1.5 & 1.2 & & 33.9 & 0.8 & 0.2 & 0.7 & 0.4 \\
\hline \multirow[t]{2}{*}{ Feb-03 } & 12.8 & 7.8 & 9.9 & 3.4 & 2.4 & Oct-04 & 26.9 & 1.4 & 0.5 & 1.1 & 0.6 \\
\hline & 7.6 & 2.4 & 2.8 & 2.3 & 2.0 & & ND & 2.8 & 3.6 & 1.5 & 0.8 \\
\hline \multirow[t]{2}{*}{ Mar-03 } & 27.2 & 3.8 & 6.5 & 1.4 & 0.6 & Nov-04 & 35.0 & 2.7 & 2.9 & 1.8 & 1.0 \\
\hline & 22.2 & 4.3 & 5.5 & 5.0 & 3.2 & & 36.1 & 31.6 & 71.1 & 2.4 & 1.5 \\
\hline \multirow[t]{2}{*}{ Apr-03 } & 11.3 & 2.8 & 1.6 & 2.3 & 2.1 & Dec-04 & 32.1 & 3.7 & 6.0 & 1.6 & 1.3 \\
\hline & 5.2 & 1.8 & 0.3 & 1.5 & 1.0 & & 29.6 & 6.6 & 12.0 & 1.6 & 0.9 \\
\hline \multirow[t]{2}{*}{ May-03 } & 17.8 & 0.9 & 0.4 & 2.3 & 1.0 & Jan-05 & 26.7 & 4.7 & 12.2 & 3.4 & 1.0 \\
\hline & 16.7 & 2.9 & 0.4 & 3.0 & 3.2 & & 26.1 & 9.1 & 14.5 & 2.8 & 1.5 \\
\hline \multirow[t]{2}{*}{ Jun-03 } & ND & 1.0 & 0.2 & 1.0 & 0.7 & Feb-05 & 23.3 & 5.8 & 13.2 & 2.2 & 1.3 \\
\hline & 20.2 & 2.7 & 0.8 & 1.9 & 1.2 & & 23.5 & 7.2 & 12.5 & 17.9 & 5.2 \\
\hline \multirow[t]{2}{*}{ Jul-03 } & ND & 0.4 & 0.1 & 0.6 & 0.4 & Mar-05 & 21.0 & 7.0 & 9.3 & 6.3 & 4.0 \\
\hline & ND & 0.3 & 0.1 & 1.1 & 0.6 & & 16.5 & 1.8 & ND & ND & ND \\
\hline \multirow[t]{2}{*}{ Aug-03 } & 28.1 & 2.6 & 0.1 & 2.1 & 1.3 & Apr-05 & 3.8 & 2.9 & 1.2 & 9.1 & 4.7 \\
\hline & 30.8 & 2.2 & 0.3 & 1.0 & 0.9 & & 10.7 & 5.2 & 1.5 & 6.0 & 4.5 \\
\hline \multirow[t]{2}{*}{ Sep-03 } & 33.3 & 4.0 & 3.1 & 1.2 & 1.5 & May-05 & 17.3 & 1.1 & 1.3 & 1.8 & 1.0 \\
\hline & 32.3 & 1.6 & 1.0 & 0.9 & 0.6 & & ND & 3.0 & 0.8 & 6.4 & 3.7 \\
\hline \multirow[t]{2}{*}{ Oct-03 } & 34.6 & 3.2 & 2.5 & 0.6 & 0.7 & Jun-05 & ND & 0.1 & 0.1 & 1.4 & 0.7 \\
\hline & 37.9 & 5.4 & 8.0 & 1.2 & 1.1 & & 12.4 & 2.6 & 0.1 & 1.6 & 0.8 \\
\hline \multirow[t]{2}{*}{ Nov-03 } & 26.7 & 2.0 & 1.1 & 1.2 & 0.6 & Jul-05 & 25.6 & 1.3 & 0.1 & 1.0 & 0.6 \\
\hline & ND & 0.1 & 6.0 & 1.2 & 0.8 & & 26.2 & 2.5 & 0.5 & 2.4 & 1.3 \\
\hline \multirow[t]{2}{*}{ Dec-03 } & 23.3 & 3.9 & 5.8 & 0.9 & 0.8 & Aug-05 & 25.0 & 2.5 & 0.1 & 0.9 & 2.1 \\
\hline & 25.6 & 6.6 & 10.3 & 1.9 & 1.8 & & 23.5 & 2.7 & 1.0 & 2.2 & 0.8 \\
\hline \multirow[t]{2}{*}{ Jan-04 } & 26.5 & 9.0 & 20.1 & 1.8 & 1.1 & Sep-05 & 23.7 & 1.6 & 2.4 & 2.1 & 1.6 \\
\hline & 27.6 & 4.6 & 8.1 & 1.6 & 0.7 & & 26.5 & 0.6 & 0.6 & 1.7 & 1.0 \\
\hline \multirow[t]{2}{*}{ Feb-04 } & 23.3 & 10.9 & 24.4 & 4.0 & 3.1 & Oct-05 & ND & 0.4 & 0.6 & 1.1 & 0.8 \\
\hline & 25.3 & 6.9 & 11.7 & 2.7 & 2.1 & & ND & 0.6 & 1.1 & 1.5 & 1.0 \\
\hline \multirow[t]{2}{*}{ Mar-04 } & ND & 5.9 & 8.1 & 4.8 & 2.6 & Nov-05 & 25.0 & 1.2 & 5.1 & 2.2 & 1.3 \\
\hline & 20.6 & 2.5 & 2.1 & 2.1 & 1.2 & & 21.1 & 6.7 & 13.9 & 3.7 & 2.7 \\
\hline \multirow[t]{2}{*}{ Apr-04 } & ND & 3.6 & 3.5 & 1.6 & 1.7 & Dec-05 & 30.5 & 9.5 & 19.9 & 2.3 & 1.4 \\
\hline & 15.7 & 2.0 & 0.9 & 3.9 & 2.2 & & 26.2 & 5.5 & 13.9 & 2.1 & 1.3 \\
\hline \multirow[t]{2}{*}{ May-04 } & ND & 0.4 & 0.4 & 1.6 & 1.1 & Jan-06 & 18.4 & 4.7 & 9.3 & 3.8 & 2.1 \\
\hline & 22.5 & 2.1 & 0.3 & 1.8 & 1.2 & & 22.0 & 11.3 & 26.6 & 2.7 & 1.3 \\
\hline \multirow[t]{2}{*}{ Jun-04 } & ND & 2.4 & 0.5 & 1.5 & 1.2 & Feb-06 & 13.8 & 5.4 & 11.8 & 3.3 & 2.3 \\
\hline & 26.3 & 1.5 & 0.5 & 1.2 & 0.9 & & 10.6 & 3.6 & 7.7 & 2.9 & 1.8 \\
\hline \multirow[t]{2}{*}{ Jul-04 } & ND & 4.7 & 0.4 & 3.5 & 2.6 & Mar-06 & 3.9 & 5.6 & 6.6 & 6.7 & 4.4 \\
\hline & 28.7 & 3.0 & 0.7 & 2.6 & 1.5 & & \multicolumn{2}{|c|}{ Not collected } & & & \\
\hline
\end{tabular}

February).

The volume-weighted annual mean boron concentration in the precipitation was $3.6 \mu \mathrm{g} \mathrm{L}^{-1}$ at the Noshiro site, $2.9 \mu \mathrm{g} \mathrm{L}^{-1}$ at the Nakanoto site, and $2.9 \mu \mathrm{g} \mathrm{L}^{-1}$ at the Matsuura site. These values were lower than those analyzed previously in different coastal sites located in the French Guiana, UK, USA and New Zealand, which ranged from 3.3 to $26.4 \mu \mathrm{g} \mathrm{L}^{-1}$ (Park and Schlesinger, 2002; Chetelat et al., 2005). The Noshiro and Nakanoto sites showed a distinct seasonal change, that is, the boron concentration in the precipitation markedly increases during winter. At the Matsuura site, however, such seasonal change tended to be erratic compared with the other sites.

The volume-weighted mean concentrations of $\mathrm{Na}^{+}$, nss- $\mathrm{SO}_{4}{ }^{2-}$ and $\mathrm{NO}_{3}{ }^{-}$in the precipitation for each season during the sampling period are shown in Table 2. The $\mathrm{Na}^{+}$ concentration at all the sites was considerably higher during winter, suggesting a large contribution of sea-salt aerosol during winter. On the other hand, the concentrations of nss- $\mathrm{SO}_{4}{ }^{2-}$ and $\mathrm{NO}_{3}{ }^{-}$were relatively high during spring as well as winter. Thus, it is likely that there is some contribution from anthropogenic combustion activities during those seasons. As shown in Fig. 3, the boron concentration in the precipitation correlated significantly with 
Table 1. (continued)

(b) Nakanoto site

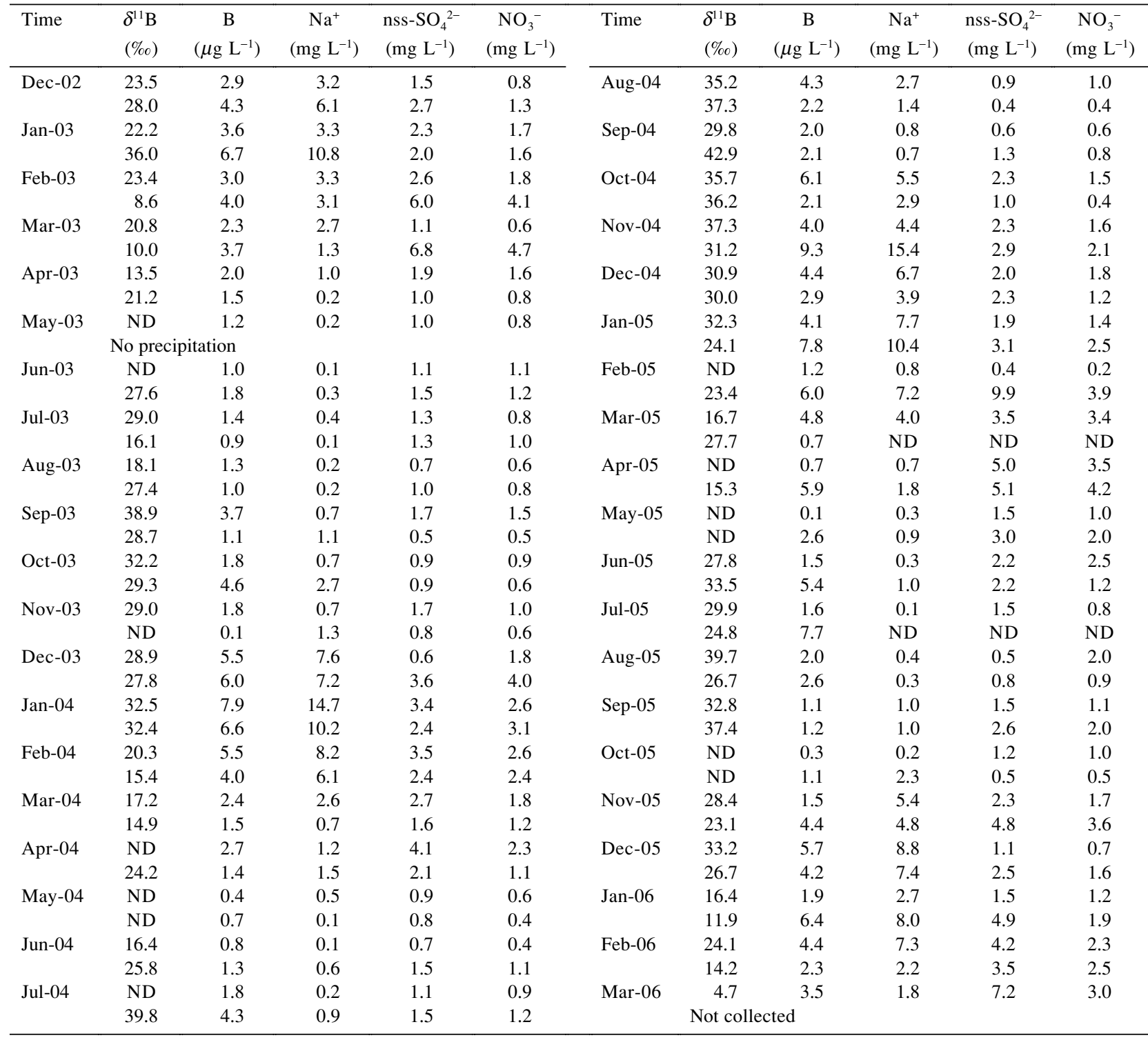

the $\mathrm{Na}^{+}$concentration at the three sites $\left(r^{2}=0.52-0.93, P\right.$ $<0.001)$. At the Matsuura site, one data showing much higher boron concentration $\left(65.0 \mu \mathrm{g} \mathrm{L}^{-1}\right)$ was excluded, assuming that this data in particular is attributable to the emissions of boron from unknown peculiar sources. A similar correlation was observed in the precipitation samples collected in the French Guiana where the boron in the precipitation is predominantly of marine origin as determined by boron isotope analysis (Chetelat et al., 2005). This strongly suggests that seawater is an important source of boron in the precipitation at the three sites on the Japan Sea coast. The enrichment factor $\left(\mathrm{EF}_{\mathrm{sw}}\right)$ of boron in the precipitation relative to seawater, which is defined as $\left(\mathrm{B} / \mathrm{Na}^{+}\right)_{\text {precipitation }} /\left(\mathrm{B} / \mathrm{Na}^{+}\right)_{\text {seawater }}$, ranged from 0.6 to 69 (average, $7 \pm 13$ ) at the Noshiro site, 0.7 to 30 (average, $6 \pm 7$ ) at the Nakanoto site, and 0.6 to 48 (average, $9 \pm 9)$ at the Matsuura site. In general, the $\mathrm{EF}_{\mathrm{sw}}$ values tended to decrease during winter (Fig. 3). At the Noshiro site located in northern Japan (Fig. 1), the $\mathrm{EF}_{\mathrm{sw}}$ values approached unity during winter, suggesting that much of the boron in the precipitation is derived from unfractionated sea salts rather than gaseous boron evaporated from seawater (Fogg and Duce, 1985). This may be related to the fact that the volatilization of boron from atmospheric sea salts can occur at high temperature (Chetelat et al., 2005). 
Table 1. (continued)

(c) Matsuura site

\begin{tabular}{|c|c|c|c|c|c|c|c|c|c|c|c|}
\hline Time & $\begin{array}{l}\delta^{11} \mathrm{~B} \\
(\% \circ)\end{array}$ & $\begin{array}{c}\mathrm{B} \\
\left(\mu \mathrm{g} \mathrm{L}^{-1}\right)\end{array}$ & $\begin{array}{c}\mathrm{Na}^{+} \\
\left(\mathrm{mg} \mathrm{L}^{-1}\right)\end{array}$ & $\begin{array}{c}\mathrm{nss} \mathrm{SO}_{4}{ }^{2-} \\
\left(\mathrm{mg} \mathrm{L}^{-1}\right)\end{array}$ & $\begin{array}{c}\mathrm{NO}_{3}^{-} \\
\left(\mathrm{mg} \mathrm{L}^{-1}\right)\end{array}$ & Time & $\begin{array}{l}\delta^{11} \mathrm{~B} \\
(\% \circ)\end{array}$ & $\begin{array}{c}\mathrm{B} \\
\left(\mu \mathrm{g} \mathrm{L}^{-1}\right)\end{array}$ & $\begin{array}{c}\mathrm{Na}^{+} \\
\left(\mathrm{mg} \mathrm{L}^{-1}\right)\end{array}$ & $\begin{array}{c}\mathrm{nss} \mathrm{SO}_{4}^{2-} \\
\left(\mathrm{mg} \mathrm{L}^{-1}\right)\end{array}$ & $\begin{array}{c}\mathrm{NO}_{3}^{-} \\
\left(\mathrm{mg} \mathrm{L}^{-1}\right)\end{array}$ \\
\hline \multirow[t]{2}{*}{ Dec-02 } & 14.9 & 2.3 & 1.3 & 1.6 & 0.9 & Aug-04 & ND & ND & 28.1 & 2.9 & 1.9 \\
\hline & 20.3 & 2.8 & 1.4 & 2.6 & 1.1 & & 35.4 & 7.7 & 11.9 & 0.2 & 0.1 \\
\hline \multirow[t]{2}{*}{ Jan-03 } & 18.8 & 5.8 & 13.0 & 2.7 & 1.6 & Sep-04 & 37.4 & 2.1 & 1.1 & 0.3 & 0.2 \\
\hline & 16.2 & 4.4 & 2.8 & 2.9 & 1.6 & & 30.3 & 3.6 & 0.8 & 1.2 & 0.6 \\
\hline \multirow[t]{2}{*}{ Feb-03 } & 11.9 & 2.6 & 1.4 & 2.0 & 1.6 & Oct-04 & \multicolumn{5}{|c|}{ No precipitation } \\
\hline & 25.6 & 6.0 & 3.3 & 5.7 & 3.6 & & 35.8 & 3.0 & 4.0 & 0.3 & 0.3 \\
\hline \multirow[t]{2}{*}{ Mar-03 } & 6.1 & 3.6 & 1.7 & 1.3 & 1.1 & Nov-04 & 20.9 & 1.2 & 0.7 & 0.6 & 0.5 \\
\hline & 20.9 & 2.2 & 0.5 & 3.2 & 1.8 & & 28.9 & 11.8 & 4.9 & 6.7 & 4.1 \\
\hline \multirow[t]{2}{*}{ Apr-03 } & 24.2 & 1.9 & 0.8 & 1.9 & 1.2 & Dec-04 & 17.9 & 0.5 & 0.3 & 0.3 & 0.4 \\
\hline & 24.3 & 3.4 & 0.3 & 1.4 & 1.1 & & 13.1 & 3.6 & 2.2 & 3.1 & 3.6 \\
\hline \multirow[t]{2}{*}{ May-03 } & 27.0 & 1.5 & 0.3 & 1.3 & 0.8 & Jan-05 & 13.2 & 8.5 & 9.6 & 5.9 & 7.7 \\
\hline & ND & 1.5 & 0.2 & 1.7 & 1.0 & & 13.5 & 6.2 & 1.9 & 4.2 & 3.7 \\
\hline \multirow[t]{2}{*}{ Jun-03 } & ND & 1.4 & 0.9 & 0.7 & 0.5 & Feb-05 & 12.7 & 3.8 & 5.0 & 2.3 & 1.5 \\
\hline & 30.2 & 4.5 & ND & ND & 0.9 & & 19.3 & 3.1 & 0.8 & 1.0 & 1.6 \\
\hline \multirow[t]{2}{*}{ Jul-03 } & 38.1 & 2.9 & 0.5 & 1.8 & 1.2 & Mar-05 & ND & 10.1 & 6.4 & 6.6 & 9.9 \\
\hline & 36.0 & 4.2 & 0.6 & 1.7 & 1.1 & & ND & 0.1 & ND & ND & ND \\
\hline \multirow[t]{2}{*}{ Aug-03 } & 32.1 & 1.6 & 0.5 & 0.9 & 0.5 & Apr-05 & 27.6 & 3.8 & 1.3 & 2.7 & 1.8 \\
\hline & 32.4 & 2.7 & 0.2 & 0.7 & 0.5 & & 27.2 & 3.1 & 0.3 & 1.4 & 0.8 \\
\hline \multirow[t]{2}{*}{ Sep-03 } & 32.0 & 4.4 & 3.3 & 0.6 & 0.5 & May-05 & ND & 1.4 & 0.3 & 2.8 & 1.3 \\
\hline & 36.4 & 24.5 & 26.6 & 2.9 & 3.1 & & 29.9 & 2.3 & 0.4 & 1.9 & 0.8 \\
\hline \multirow[t]{2}{*}{ Oct-03 } & 32.2 & 11.9 & 6.1 & 2.3 & 2.7 & Jun-05 & ND & 2.3 & 0.4 & 2.0 & 1.1 \\
\hline & \multicolumn{2}{|c|}{ No precipitation } & & & & & 20.2 & 11.5 & 1.1 & 5.3 & 5.7 \\
\hline \multirow[t]{2}{*}{ Nov-03 } & 20.8 & 3.4 & 1.0 & 0.8 & 0.9 & Jul-05 & 28.6 & 3.1 & 0.5 & 2.3 & 1.2 \\
\hline & ND & 0.1 & 0.9 & 1.0 & 1.4 & & ND & 2.3 & 0.5 & 1.1 & 0.7 \\
\hline \multirow[t]{2}{*}{ Dec-03 } & 4.6 & 6.2 & 2.0 & 1.7 & 1.8 & Aug-05 & 32.6 & 1.7 & 0.3 & 0.8 & 1.6 \\
\hline & 3.1 & 14.7 & 20.3 & 12.4 & 8.6 & & ND & 0.3 & 0.2 & 0.5 & 0.3 \\
\hline \multirow[t]{2}{*}{ Jan-04 } & ND & 2.2 & 1.8 & 1.9 & 1.4 & Sep-05 & ND & 0.1 & 0.4 & 0.2 & 0.1 \\
\hline & 14.4 & 9.6 & 9.7 & 3.7 & 2.9 & & ND & 1.8 & 0.7 & 2.4 & 1.3 \\
\hline \multirow[t]{2}{*}{ Feb-04 } & 18.2 & 16.2 & ND & ND & ND & Oct-05 & 14.4 & 4.0 & 0.9 & 1.8 & 2.4 \\
\hline & 28.5 & 3.1 & 0.9 & 1.9 & 0.9 & & ND & 1.9 & 1.8 & 1.8 & 1.1 \\
\hline \multirow[t]{2}{*}{ Mar-04 } & 8.7 & 9.0 & 10.1 & 9.1 & 5.5 & Nov-05 & ND & 0.3 & 0.3 & 1.1 & 0.4 \\
\hline & 23.2 & 1.3 & 0.3 & 0.7 & 0.4 & & 13.4 & 8.2 & 3.5 & 5.0 & 6.4 \\
\hline \multirow[t]{2}{*}{ Apr-04 } & ND & 14.9 & 1.4 & 10.6 & 6.1 & Dec-05 & 22.9 & 8.6 & 11.0 & 4.1 & 3.2 \\
\hline & 41.8 & 2.4 & 1.7 & 1.4 & 0.9 & & 26.4 & 9.5 & 18.8 & 4.5 & 4.0 \\
\hline \multirow[t]{2}{*}{ May-04 } & 48.7 & 1.7 & 0.4 & 1.1 & 0.6 & Jan-06 & ND & 0.9 & 0.3 & 1.6 & 0.6 \\
\hline & 29.4 & 2.0 & 0.1 & 1.0 & 0.7 & & -16.1 & 65.0 & 3.6 & 5.3 & 6.5 \\
\hline \multirow[t]{2}{*}{ Jun-04 } & 30.0 & 2.4 & 0.4 & 1.2 & 1.2 & Feb-06 & 26.0 & 3.6 & 3.8 & 3.7 & 1.7 \\
\hline & 32.4 & 2.0 & 0.5 & 0.8 & 0.5 & & 12.4 & 1.1 & 0.5 & 1.4 & 0.7 \\
\hline \multirow[t]{2}{*}{ Jul-04 } & ND & 2.7 & 0.9 & 0.9 & 0.6 & Mar-06 & 10.6 & 2.9 & 1.2 & 3.8 & 2.0 \\
\hline & 28.9 & 5.8 & 0.5 & 4.0 & 2.6 & & \multicolumn{2}{|c|}{ Not collected } & & & \\
\hline
\end{tabular}

ND: Not determined.

Table 2. Volume-weighted mean concentrations of $\mathrm{Na}^{+}, \mathrm{nSS}_{-} \mathrm{SO}_{4}{ }^{2-}$ and $\mathrm{NO}_{3}{ }^{-}$in precipitation for each season from December 2002 to March 2006 at Noshiro, Nakanoto and Matsuura sites

\begin{tabular}{|c|c|c|c|c|c|c|c|c|c|}
\hline & \multicolumn{3}{|c|}{$\mathrm{Na}^{+}\left(\mathrm{mg} \mathrm{L}^{-1}\right)$} & \multicolumn{3}{|c|}{$\mathrm{nss}-\mathrm{SO}_{4}{ }^{2-}\left(\mathrm{mg} \mathrm{L}^{-1}\right)$} & \multicolumn{3}{|c|}{$\mathrm{NO}_{3}^{-}\left(\mathrm{mg} \mathrm{L}^{-1}\right)$} \\
\hline & Noshiro & Nakanoto & Matsuura & Noshiro & Nakanoto & Matsuura & Noshiro & Nakanoto & Matsuura \\
\hline Spring & 2.5 & 0.94 & 0.74 & 3.7 & 2.2 & 1.7 & 2.4 & 1.8 & 1.2 \\
\hline Summer & 1.5 & 0.46 & 1.1 & 1.4 & 1.1 & 1.2 & 0.91 & 0.93 & 0.62 \\
\hline Fall & 4.9 & 2.6 & 1.9 & 1.3 & 1.6 & 0.85 & 0.91 & 1.2 & 0.83 \\
\hline Winter & 13 & 6.9 & 4.3 & 2.7 & 2.7 & 3.7 & 1.5 & 2.0 & 2.6 \\
\hline
\end{tabular}



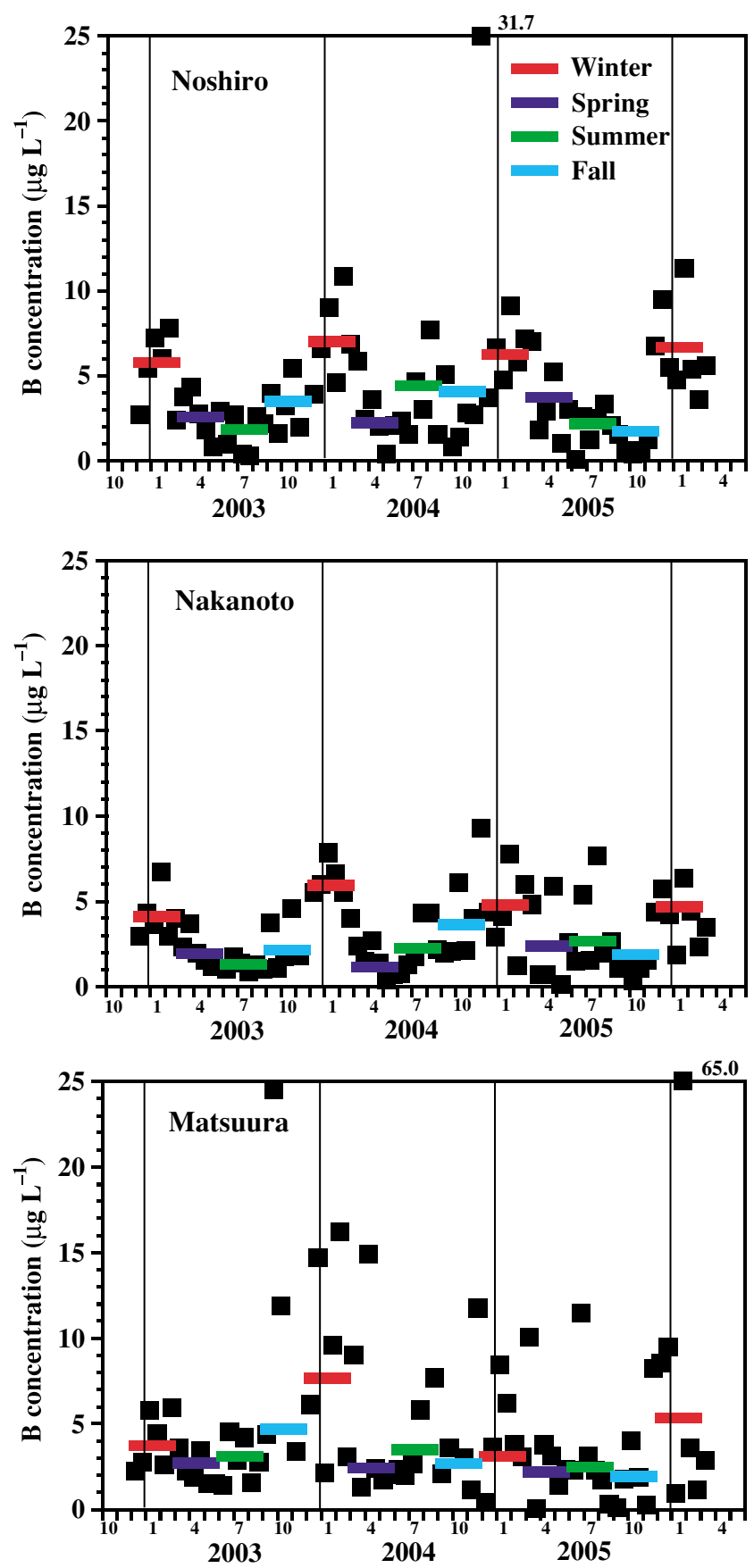

Fig. 2. Temporal changes in boron concentration in precipitation from December 2002 to March 2006 at Noshiro, Nakanoto and Matsuura sites. Each bar represents a weighted mean boron concentration for each season.

\section{Boron isotope ratio in precipitation}

After the concentration of the precipitation samples using the ion exchange resin, a boron solution of 5 to 50 $\mu \mathrm{g} \mathrm{L}^{-1}$ was needed to obtain a good precision $(\sim 0.4 \%$ as $\mathrm{RSD}$ ) for boron isotope analysis. Hence, the boron iso-
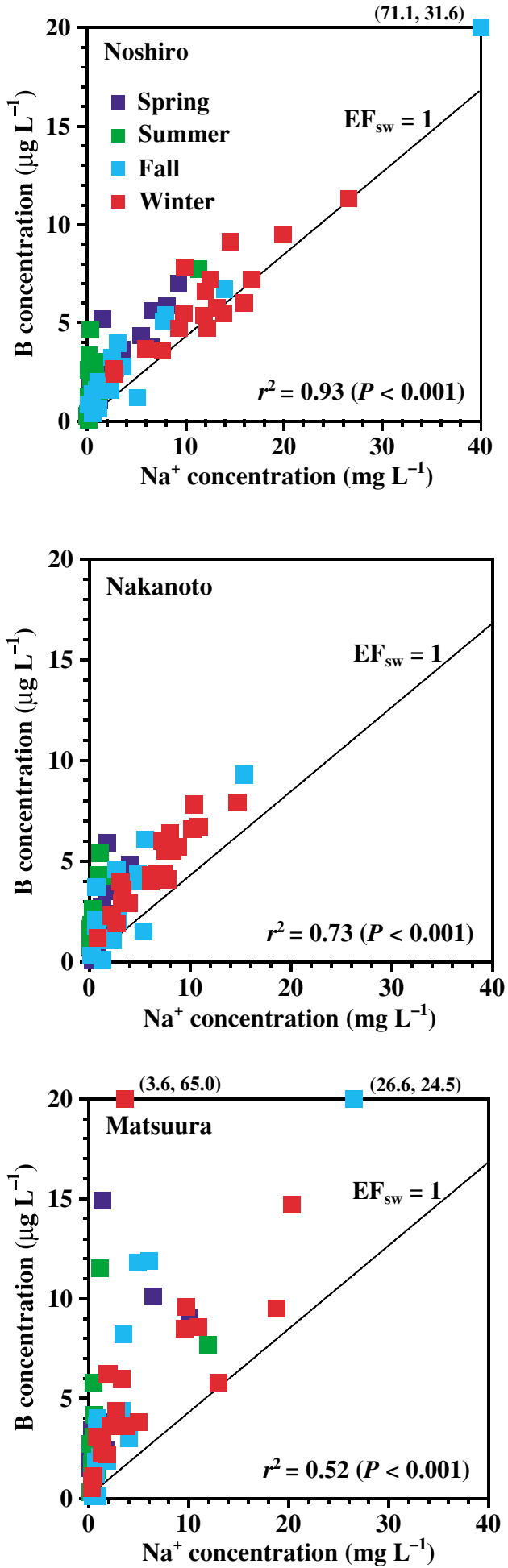

Fig. 3. Relationship between boron concentration and $\mathrm{Na}^{+}$ concentration in precipitation at Noshiro, Nakanoto and Matsuura sites. The enrichment factor $\left(E F_{\text {sw }}\right)$ is calculated assuming that all the $\mathrm{Na}^{+}$is derived from dissolution of sea salts (see text for details). 
tope analysis was not carried out for some samples having small volume and low concentration (approximately $<1 \mu \mathrm{g} \mathrm{L}^{-1}$; see Table 1) of boron. The temporal changes in $\delta^{11} \mathrm{~B}$ in the precipitation from December 2002 to March 2006 at the Noshiro, Nakanoto and Matsuura sites are indicated in Fig. 4. The seasonal averages, which were weighted on the basis of the boron wet deposition flux for each sampling period, are also provided in the figure.

Figure 4 shows that the $\delta^{11} \mathrm{~B}$ of the precipitation at the three sites has a maximum close to that $(+39.5 \%)$ of seawater, and markedly decreases during spring at the Noshiro and Nakanoto sites and during winter at the Matsuura site. Thus, the seasonal change in the $\delta^{11} \mathrm{~B}$ was not consistent among the three sites, which is different from that in the case of the boron concentration (Fig. 2). On the whole, the $\delta^{11} \mathrm{~B}$ values (weighted mean $=+26-$ $+28 \%$ ) at the three sites were not significantly different from those $(+19-+35 \%$ o $)$ of rainwater collected mostly over the North Pacific (Miyata et al., 2000). Also, they were lower than those (weighted mean $=+41 \%$ ) in the French Guiana (Chetelat et al., 2005) but higher than those (median $=+16 \%$ ) in the UK (Mather and Porteous, 2001).

Rose-Koga et al. (2006) inferred that the $\delta^{11} \mathrm{~B}$ of the precipitation can be related to that of the seawater reservoir by the seawater-vapor fractionation and one or more processes, including (1) the rain-vapor isotopic fractionation, (2) evolution of the $\delta^{11} \mathrm{~B}$ of the atmospheric vapor reservoir via condensation-precipitation processes (Rayleigh distillation process), (3) contribution of vapor from the evaporation of seawater aerosols, and (4) contribution of particulate matter from natural and anthropogenic sources. Chetelat et al. (2005) reported that a significant correlation between $\delta^{11} \mathrm{~B}$ and $\mathrm{NO}_{3}{ }^{-} / \mathrm{B}$ ratio was observed in the French Guiana's precipitation, indicating that boron in the precipitation originates from two sources. The first source (characterized by high $\delta^{11} \mathrm{~B}$ and low $\mathrm{NO}_{3}{ }^{-}$ /B) is certainly seawater, and they proposed that biomass burning is the most likely second source (characterized by lower $\delta^{11} \mathrm{~B}$ and higher $\left.\mathrm{NO}_{3}^{-} / \mathrm{B}\right)$. Rose-Koga et al. (2006) supported this interpretation because the observed decrease in $\delta^{11} \mathrm{~B}$ of the precipitation is probably not associated with a Rayleigh distillation process because $\delta \mathrm{D}$ does not decrease (a Rayleigh process is characterized by the boron meteoric water line: $\delta \mathrm{D}=2.6 \delta^{11} \mathrm{~B}-133$ ). Satake (1986) measured $\delta \mathrm{D}$ in the precipitation samples collected at Toyama on the Japan Sea coast, which is located close to the Nakanoto site (approximately $40 \mathrm{~km}$ southeast; Fig. 1). There is no significant difference in altitude $(<100 \mathrm{~m})$ between Toyama and the study sites. The $\delta \mathrm{D}$ values showed a small change, ranging from approximately -60 to $0 \%$ independent of season. Similar to the case of the French Guiana's precipitation, it is not likely that the decrease in $\delta^{11} \mathrm{~B}$ observed during winter or spring at the Noshiro, Nakanoto and Matsuura sites (Fig.
4) is associated with a Rayleigh distillation process. It is known that $\mathrm{B}(\mathrm{OH})_{3}$ and $\mathrm{B}(\mathrm{OH})_{4}{ }^{-}$isotopic compositions in solution depend on $\mathrm{pH}$. Because $\mathrm{B}(\mathrm{OH})_{3}$ is preferentially evaporated, the boron isotopic fractionation taking place between precipitation and vapor is mostly that between $\mathrm{B}(\mathrm{OH})_{3}$ dissolved in liquid water and gaseous $\mathrm{B}(\mathrm{OH})_{3}$. However, this does not cause the seasonal changes in the $\delta^{11} \mathrm{~B}$ of the precipitation at the study sites, because $\mathrm{B}(\mathrm{OH})_{3}$ is by far the dominant species in the precipitation throughout the year owing to its relatively low $\mathrm{pH}(<5)$.

Ikeda and Higashino (1997) and Ichikawa et al. (1998) estimated the contribution of $\mathrm{SO}_{2}$ sources to nss- $\mathrm{SO}_{4}{ }^{2-}$ wet deposition in Japan using a long-range transport model for East Asia. The results showed that the contributions of Japanese anthropogenic sources, volcanic eruptions and Asian continental sources (primarily in China and Korea) to the annual deposition in the entire Japan were 29, 20 and 51\%, respectively. For the Japan Sea side, the contribution $(>70 \%)$ of the Asian continent sources was much higher than that of other sources, particularly during the cold season (October-March) when the airflows from the Asian continent are dominant. Moreover, Ikeda and Higashino (1997) reported that the $\mathrm{NO}_{\mathrm{x}}$ sources in China and Korea also substantially contribute to $\mathrm{NO}_{3}{ }^{-}$ wet deposition at the Japan Sea side. In fact, there was a significant correlation $\left(r^{2}=0.73-0.77, P<0.001\right)$ between the concentrations of $\mathrm{nss}-\mathrm{SO}_{4}{ }^{2-}$ and $\mathrm{NO}_{3}{ }^{-}$in the precipitation collected at the Noshiro, Nakanoto and Matsuura sites. Thus, most of the nss- $\mathrm{SO}_{4}{ }^{2-}$ and $\mathrm{NO}_{3}{ }^{-}$in those samples are derived from anthropogenic combustion activities in the Asian continent. It is assumed that the contribution of volcanic eruptions to boron wet deposition at the Japan Sea side is also very small based on the results of simulation for nss- $\mathrm{SO}_{4}{ }^{2-}$ wet deposition described above. If boron in the precipitation originates simply from two sources, i.e., seawater and anthropogenic emissions in the Asian continent, a significant correlation should be observed between $\delta^{11} \mathrm{~B}$ and nss- $\mathrm{SO}_{4}{ }^{2-} / \mathrm{B}$ or $\mathrm{NO}_{3}{ }^{-} / \mathrm{B}$ ratio.

The relationship between $\delta^{11} \mathrm{~B}$ and nss- $\mathrm{SO}_{4}{ }^{2-} / \mathrm{B}$ in the precipitation at the study sites was investigated (Fig. 5). At the Matsuura site, one data showing much lower $\delta^{11} \mathrm{~B}$ $(-16.1 \% o)$ and much higher boron concentration $(65.0 \mu \mathrm{g}$ $\mathrm{L}^{-1}$ ) was excluded, assuming that this data in particular is attributable to the emissions of boron from unknown peculiar sources. A weak correlation $\left(r^{2}=0.13-0.24, P<\right.$ $0.01)$ was observed between $\delta^{11} \mathrm{~B}$ and $\mathrm{nss}-\mathrm{SO}_{4}{ }^{2-} / \mathrm{B}$ ratio at each site. In addition, there was a similar correlation $\left(r^{2}=0.13-0.28, P<0.01\right)$ between $\delta^{11} \mathrm{~B}$ and $\mathrm{NO}_{3}{ }^{-} / \mathrm{B}$ at each site. These suggest that boron in the precipitation originate primarily from two sources. That is, the first source, which is characterized by high $\delta^{11} \mathrm{~B}$ and nss- $\mathrm{SO}_{4}{ }^{2-}$ $/ \mathrm{B}=0$, is seawater. The second source, which is characterized by low $\delta^{11} \mathrm{~B}$ and high nss- $\mathrm{SO}_{4}{ }^{2-} / \mathrm{B}$ ratio, is the 

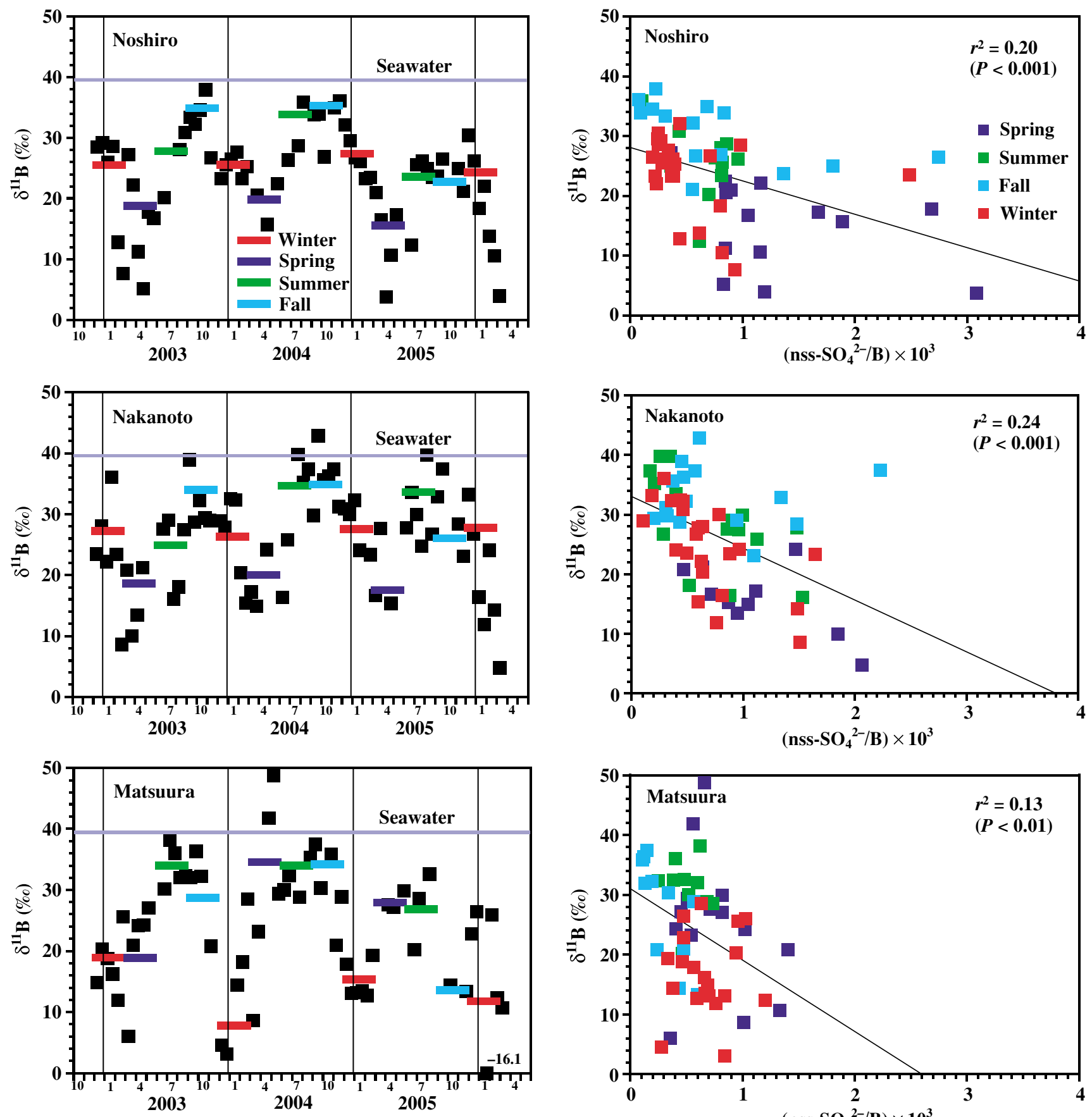

Fig. 4. Temporal changes in $\delta^{11} B$ in precipitation from December 2002 to March 2006 at Noshiro, Nakanoto and Matsuura sites. Each bar represents a weighted mean $\delta^{I l} B$ for each season.

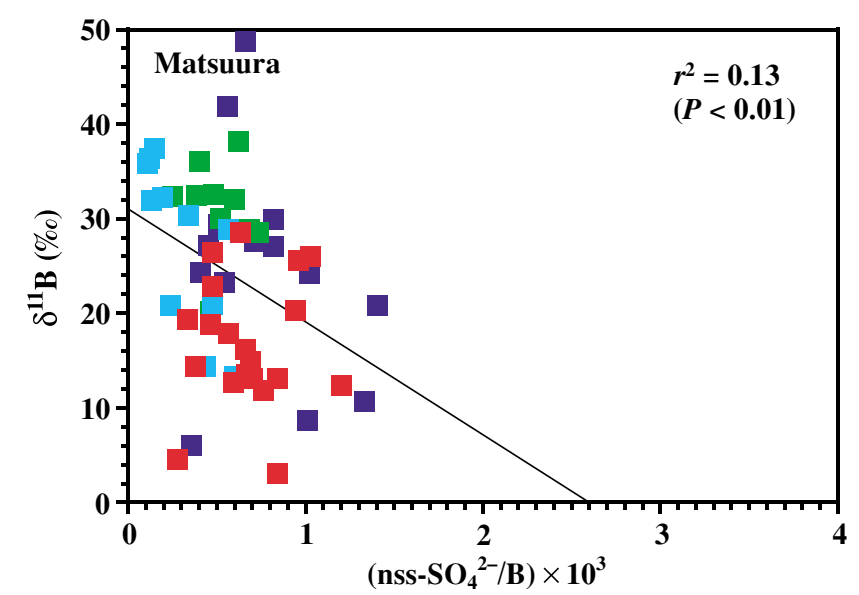

Fig. 5. Relationship between $\delta^{l 1} B$ and $n s s-S_{4}{ }^{2-} / B$ ratio at Noshiro, Nakanoto and Matsuura sites. Lines in the figures represent regression lines.

anthropogenic emissions in the Asian continent. Coal enriches boron and represents generally negative $\delta^{11} \mathrm{~B}$ values (Williams and Hervig, 2004). In addition, coal accounts for a major portion of the total primary energy supply in China (International Energy Agency, 2008).

Hence, we propose the emission of boron from coal burning as the most likely second source.

As mentioned previously, the $\mathrm{EF}_{\mathrm{sw}}$ values at the Noshiro site approached unity during winter (Fig. 3), suggesting that much of the boron in the precipitation is de- 
rived from unfractionated sea salts rather than gaseous boron evaporated from seawater. Therefore, the unfractionated sea salts are assumed as the first boron source in the precipitation during winter at the Noshiro site. Taking $+39.5 \%$ as its $\delta^{11} \mathrm{~B}\left(\delta^{11} \mathrm{~B}_{\text {sea salt }}\right)$, the $\delta^{11} \mathrm{~B}$ $\left(\delta^{11} \mathrm{~B}_{\text {second }}\right)$ of the second boron source can be calculated using a mass balance equation based on boron isotopes.

$$
\delta^{11} \mathrm{~B}_{\text {second }}=\frac{\delta^{11} \mathrm{~B}_{\text {precipitation }}-r \delta^{11} \mathrm{~B}_{\text {sea salt }}}{1-r}
$$

Here, $\delta^{11} \mathrm{~B}_{\text {precipitation }}$ is $\delta^{11} \mathrm{~B}$ of the precipitation sample and $r$ is the fraction of boron originating from unfractionated sea salts in the precipitation. The parameter $r$ is calculated using the following equation: $r=(\mathrm{B} /$ $\left.\mathrm{Na}^{+}\right)_{\text {seawater }} /\left(\mathrm{B} / \mathrm{Na}^{+}\right)_{\text {precipitation, }}$, where $\left(\mathrm{B} / \mathrm{Na}^{+}\right)_{\text {seawater }}$ and $(\mathrm{B} /$ $\left.\mathrm{Na}^{+}\right)_{\text {precipitation }}$ represent the concentration ratios of boron and $\mathrm{Na}^{+}$in seawater and precipitation, respectively. The result yielded approximately -1 to $-84 \%$ as $\delta^{11} \mathrm{~B}$ of the second source when the $\mathrm{EF}_{\mathrm{sw}}$ values range from 1.2 to 2.1. This may support our interpretation that the second source is the coal burning in the Asian continent. It is likely that boron in the precipitation on the Japan Sea coast is considerably affected by the long-range transport of coal-burning plumes from the Asian continent to Japan during winter and spring. Thus, boron isotopes may be useful as tracers of such coal-burning plumes. It is advantageous that their measurement can be easily conducted by ICP-QMS, which is currently widely used as a tool for trace element analysis.

However, the data on the relationship between $\delta^{11} \mathrm{~B}$ and nss- $\mathrm{SO}_{4}{ }^{2-} / \mathrm{B}$ ratio were highly scattered (Fig. 5). This suggests a limitation in the application of the simple twocomponent end-member model that is the same as that used for the French Guiana's precipitation. One reason is the fact that the $\delta^{11} \mathrm{~B}$ of coals is strongly dependent on the origin of the coals, e.g., marine or nonmarine. Nomura et al. (1990) reported that coals deposited in the marine environment have relatively high $\delta^{11} \mathrm{~B}$ values. For $\delta^{34} \mathrm{~S}$ values, northern Chinese coals are known to have higher values than southern Chinese coals, reflecting the difference in the origin of the coals between the two regions (Maruyama et al., 2000). The other reason is contribution of biomass burning (e.g., wild fires and biofuel) in Asian countries and Russia, because biomass burning can release significant amounts of boron to the atmosphere (Fogg and Duce, 1985). Boron emissions from the combustion of biofuel in China and other countries are considered to be much smaller than those of coal on the basis of the total primary energy supply (International Energy Agency, 2008), but emissions from wild fires of natural origin remain unknown. Thus, a complex mixture of emissions from coal and possibly biomass burning with various $\delta^{11} \mathrm{~B}$ values may actually contribute to the inclusion of boron in the precipitation at the study sites. This should be confirmed by obtaining more data on boron concentration and isotopic composition in the coal and biomass used in the Asian continent and also in the air and aerosol samples there.

Acknowledgments-Precipitation sampling and some of the analyses were conducted by the Central Research Institute of Electric Power Industry, where M.S. was research scientist, under contract with the Ministry of Economy, Trade and Industry in the fiscal year 2002-2006. We wish to thank A. Tanaka (National Institute for Environmental Studies) for helpful information on boron isotope analysis and T. Okabe and $\mathrm{K}$. Fukumori (Electric Power Engineering System Co., Ltd.) for assistance with the analyses. This study was supported partially by a grant from the Sumitomo Foundation (No. 073052).

\section{REFERENCES}

Anderson, D. L., Kitto, M. E., McCarthy, L. and Zoller, W. H. (1994) Sources and atmospheric distribution of particulate and gas phase boron. Atmos. Environ. 28, 1401-1410.

Chetelat, B., Gaillardet, J., Freydier, R. and Négrel, Ph. (2005) Boron isotopes in precipitation: experimental constraints and field evidence from French Guiana. Earth Planet. Sci. Lett. 235, 16-30.

Fogg, T. R. and Duce, R. A. (1985) Boron in the troposphere: distribution and fluxes. J. Geophys. Res. 90(D2), 37813796.

Ichikawa, Y., Hayami, H. and Fujita, S. (1998) A long-range transport model for East Asia to estimate sulfur deposition in Japan. J. Appl. Meteor. 37, 1364-1374.

Ikeda, Y. and Higashino, H. (1997) The estimation of acid deposition in East Asia (II)-forcused on the ratio of sources contribution of the deposition. J. Jpn. Soc. Atmos. Environ. 32, 175-186 (in Japanese).

International Energy Agency (2008) IEA Energy Statistics 2005. http://www.iea.org/Textbase/country/index.asp

Ito, S., Yokoyama, T. and Asakura, K. (2006) Emissions of mercury and other trace elements from coal-fired power plants in Japan. Sci. Total Environ. 368, 397-402.

Jaffe, D. A., Prestbo, E., Swartzendruber, P., Weiss-Penzias, P., Kato, S., Takami, A., Hatakeyama, S. and Kaji, Y. (2005) Export of atmospheric mercury from Asia. Atmos. Environ. 39, 3029-3038.

Kagawa, M., Ishizaka, Y. and Ohta, K. (2003) Sources of sulfate in winter aerosols over the Sea of Japan, as inferred from selenium composition. Atmos. Environ. 37, 1593-1600.

Kakihana, H., Kotaka, M., Satoh, S., Nomura, M. and Okamoto, M. (1977) Fundamental studies on the ion-exchange separation of boron isotopes. Bull. Chem. Soc. Jpn. 50, 158163.

Kanzaki, T., Yoshida, M., Nomura, M., Kakihana, H. and Ozawa, T. (1979) Boron isotopic composition of fumarolic condensates and sassolites from Satsuma Iwo-jima, Japan. Geochim. Cosmochim. Acta 43, 1859-1863.

Kiss, E. (1988) Ion exchange separation and spectrophotomet- 
ric determination of boron in geologic materials. Anal. Chim. Acta 211, 243-256.

Kitamura, M., Sugiyama, M., Ohhashi, T. and Nakai, N. (1993). An estimation of the origin of sulfate ion in rain water in view of sulfur isotopic variations. Chikyukagaku (Geochemistry) 27, 109-118 (in Japanese).

Leeman, W. P., Vocke, R. D., Beary, E. S. and Paulsen, P. J. (1991) Precise boron isotopic analysis of aqueous samples: ion exchange extraction and mass spectrometry. Geochim. Cosmochim. Acta 55, 3901-3907.

Maruyama, T., Ohizumi, T., Taneoka, Y., Minami, N., Fukuzaki, N., Mukai, H., Murano, K. and Kusakabe, M. (2000) Surfur isotope ratios of coals and oils used in China and Japan. Nippon Kagaku Kaishi No. 1, 45-51 (in Japanese).

Mather, J. D. and Porteous, N. C. (2001) The geochemistry of boron and its isotopes in groundwaters from marine and nonmarine sandstone aquifers. Appl. Geochem. 16, 821-834.

Meij, R. and Te Winkel, H. (2007) The emissions of heavy metals and persistent organic pollutants from modern coalfired power stations. Atmos. Environ. 41, 9262-9272.

Miyata, Y., Tokieda, T., Amakawa, H., Uematsu, M. and Nozaki, Y. (2000) Boron isotope variations in the atmosphere. Tellus 52B, 1057-1065.

Mukai, H., Ambe, Y., Shibata, K., Muku, T., Takeshita, K., Fukuma, T., Takahashi, J. and Mizota, S. (1990) Long-term variation of chemical composition of atmospheric aerosol on the Oki Islands in the Sea of Japan. Atmos. Environ. 24A, 1379-1390.

Mukai, H., Tanaka, A., Fujii, T. and Nakao, M. (1994) Lead isotope ratios of airborne particulate matter as tracers of long-range transport of air pollutants around Japan. $J$. Geophys. Res. 99, 3717-3726.

Nakamura, E., Ishikawa, T., Brick, J.-L. and Allègre, C. J. (1992) Precise boron isotopic analysis of natural rock samples using a boron-mannitol complex. Chem. Geol. 94, 193-204.

Nomura, M., Kanzaki, T., Ozawa, T., Okamoto, M. and Kakihana, H. (1982) Boron isotopic composition of fumarolic condensates from some volcanoes in Japanese island arcs. Geochim. Cosmochim. Acta 46, 2403-2406.

Nomura, M., Fujii, Y. and Okamoto, M. (1990) The isotopic ratios of boron in coals. Shitsuryo Bunseki (Mass Spectrometry) 38, 95-100 (in Japanese).

Palmer, M. R. and Sturchio, N. C. (1990) The boron isotope systematics of the Yellowstone National Park (Wyoming) hydrothermal system: A reconnaissance. Geochim. Cosmochim. Acta 54, 2811-2815.

Park, H. and Schlesinger, W. H. (2002) Global biogeochemical cycle of boron. Global Biogeochem. Cycles 16, 1-11.

Rose-Koga, E. F., Sheppard, S. M. F., Chaussidon, M. and Carignan, J. (2006) Boron isotopic composition of atmospheric precipitations and liquid-vapour fractionations. Geochim. Cosmochim. Acta 43, 1859-1863.

Sakata, M. and Asakura, K. (2007) Estimating contribution of precipitation scavenging of atmospheric particulate mercury to mercury wet deposition in Japan. Atmos. Environ. 41, 1669-1680.

Sakata, M. and Marumoto, K. (2005) Wet and dry deposition fluxes of mercury in Japan. Atmos. Environ. 39, 3145-3152.

Sakata, M., Marumoto, K., Narukawa, M. and Asakura, K. (2006) Regional variations in wet and dry deposition fluxes of trace elements in Japan. Atmos. Environ. 40, 521-531.

Satake, H. (1986) Environmental isotope hydrology of precipitations in Toyama, Central Japan. Chikyukagaku (Geochemistry), 20, 90-92 (in Japanese).

Tanaka, N. and Sakata, M. (2002) Effect of photooxidation on $\delta^{13} \mathrm{C}$ of benzo(a)pyrene and benzo(e)pyrene in the atmosphere. Geochem. J. 36, 235-245.

Tanimoto, H., Sawa, Y., Matsueda, H., Uno, I., Ohara, T., Yamaji, K., Kurokawa, J. and Yonemura, S. (2005) Significant latitudinal gradient in the surface ozone spring maximum over East Asia. Geophys. Res. Lett. 32, L21805, doi:10.1029/2005GL023514.

Weiss-Penzias, P., Jaffe, D. A., Swartzendruber, P., Dennison, J. B., Chand, D., Hafner, W. and Prestbo, E. (2006) Observations of Asian air pollution in the free troposphere at Mount Bachelor Observatory during the spring of 2004. $J$. Geophys. Res. 111, D10304, doi:10.1029/2005JD006522.

Williams, L. B. and Hervig, R. L. (2004) Boron isotope composition of coals: a potential tracer of organic contaminated fluids. Appl. Geochem. 19, 1625-1636. 